\title{
A Simple Method for the Characterization of Antioxidant Property of Different Extracts of Bark of Gethi (Boehmeria rugulosa)
}

\author{
Anubhuti Sharma*, Rajesh Khulbe, Salej Sood, Pawan Kumar Agrawal, \\ Jagdish Chandra Bhatt and Arunav Pattanayak
}

\author{
ICAR-Vivekananda Institute of Hill Agriculture Almora, Uttarakhand-263 601, India \\ *Corresponding author
}

\begin{tabular}{|c|c|}
\hline & A B S T R A C T \\
\hline Keywords & \multirow{4}{*}{$\begin{array}{l}\text { Boehmeria rugulosa is a multipurpose tree of Urticaceae family and is widely distributed } \\
\text { in Indian Himalayas. The tree is used mainly for fodder and for making traditional bowls } \\
\text { and vessels. The bark is also reported to be used for making bread of non-glutenous crops } \\
\text { soft and tasty. The bark of the tree is known to possess medicinal properties as well. The } \\
\text { available information on its potential bioactivity and antioxidant property, however, is } \\
\text { meagre. The study on the antioxidant property of the B. rugulosa bark was, therefore, } \\
\text { undertaken. The antioxidant property of methanol, acetone and acidified methanol extracts } \\
\text { of the bark with three different concentrations }(0.5 \mathrm{mg} / \mathrm{ml}, 5 \mathrm{mg} / \mathrm{ml} \text { and } 10 \mathrm{mg} / \mathrm{ml} \text { ) was } \\
\text { determined by phytochemical screening, estimation of total phenolics, total antioxidant } \\
\text { activity, total flavonoids and in vitro antioxidant screening models viz., DPPH scavenging } \\
\text { activity, ferric reducing antioxidant power (FRAP) and ABTS scavenging activity. The } \\
\text { methanolic extracts for } 5 \mathrm{mg} / \mathrm{ml} \text { concentration showed marked quantity of phenolics and } \\
\text { flavonoids and promising levels of antioxidant activity followed by acidified methanol and } \\
\text { acetone extracts, indicating potency of the methanolic extracts for therapeutic applications. }\end{array}$} \\
\hline $\begin{array}{l}\text { Gethi, Boehmeria } \\
\text { regulosa, } \\
\text { Antioxidant } \\
\text { activity, Phenolic } \\
\text { content, DPPH, } \\
\text { ABTS }\end{array}$ & \\
\hline Article Info & \\
\hline $\begin{array}{l}\text { Accepted: } \\
\text { 25 March } 2017 \\
\text { Available Online: } \\
10 \text { April } 2017\end{array}$ & \\
\hline
\end{tabular}

\section{Introduction}

Free radicals are toxic by-products formed naturally as a result of aerobic metabolism in our body. Free radicals include reactive oxygen species (ROS) and reactive nitrogen species (RNS) (Naskar et al., 2011). Antioxidants are radical scavengers which protect the human body against free radicals stress that may cause severe diseases (Kokczka et al., 2015). Plants are potent biochemical factories and have been components of phytomedicine since time immemorial. These plant-based active components can be derived from any part of plant like bark, leaves, flowers, roots, fruits, seeds, etc. (Venkateswara Rao et al., 2013;
Anubhuti et al., 2016). The beneficial medicinal effects of plant materials typically result from the combinations of secondary metabolites present in the plant. Secondary metabolites from plants have important biological and pharmacological activities, such as anti-oxidative, anti-allergic, antibiotic, hypoglycemic and anti-carcinogenic (Borneo et al., 2008; Katalinic et al., 2004; Mulabagal and Tsay, 2004; Sharma et al., 2016). Subsequently antioxidant-based drugs or formulations have gained appreciation for the prevention and treatment of complex diseases like atherosclerosis, stroke, diabetes, Alzheimer's disease, and cancer (Adamu et 
al., 2014; Devasagayam et al., 2004). Major active antioxidant compounds include flavonoids, phenolics, lignans, and catechins etc. It has been reported that flavonoids and phenolic acids are widely distributed as secondary metabolites with antioxidant properties (Sharma et al., 2013; Margaret et al., 2015). The bark of Boehmeria rugulosa possesses high antioxidant activity and contains appreciable amounts of iron and zinc (Khulbe et al., 2014). However, the extent of antioxidant content in the bark powder and the appropriate concentration with polar extract for suitable pharmaceutical application is not available. The present work, therefore, was undertaken to determine the optimum concentration at which total phenolic content and flavonoids in various extracts of the Gethi (Boehmeria rugulosa) are highest, as well as to examine antioxidant activity of the plant extracts using in vitro model system.

\section{Materials and Methods}

\section{Plant material}

Bark samples of the Boehmeria rugulosa were collected from north western hills of Uttarakhand, India and thoroughly dried under sunlight. Dried samples were ground into a uniform powder using a blender and stored in polythene bags at room temperature.

Total phenols, flavonoid and antioxidant properties in powdered bark samples were determined. Antioxidant activity was further evaluated by measuring DPPH activity, FRAP value and ABTS activity.

\section{Sample preparation}

Samples were extracted by a minor modification of the method of Rehman (2006) and Demiray et al., (2009) using three solvent systems (methanol, acetone and acidified methanol) with three different concentrations
$(0.5 \mathrm{mg} / \mathrm{ml}, 5 \mathrm{mg} / \mathrm{ml}$ and $10 \mathrm{mg} / \mathrm{ml})$. The samples were homogenized in pestle and mortar at room temperature with the three different solvents. Extracts were centrifuged at $4000 \mathrm{rpm}$ for $30 \mathrm{~min}$ and the residues were re-extracted under the same conditions. Supernatants were pooled and mixed. Extracts were stored at $4^{0} \mathrm{C}$ for biochemical studies.

\section{Total phenolic content}

The total phenolic content was determined by the Folin-Ciocalteu method as described by Singleton et al., (1999). Appropriate volume $(0.1 \mathrm{ml})\left(1 \mathrm{mg} \mathrm{ml}^{-1}\right)$ of the extracts was briefly oxidized with Folin-Ciocalteu reagent $(0.75 \mathrm{ml})$ and the reaction was neutralized with sodium carbonate. Absorbance was measured at $725 \mathrm{~nm}$. The results were expressed as gallic acid equivalents $(\mathrm{g} / 100 \mathrm{~g}$ as GAE).

\section{Total antioxidant activity}

Total antioxidant activity was estimated using the method of Prieto et al., (1999) with slight modification. $1.23 \mathrm{ml}$ of reagent solution $(0.6$ M sulphuric acid, $28 \mathrm{mM}$ sodium phosphate and $4 \mathrm{mM}$ ammonium molybdate) was added to $20 \mu \mathrm{l}$ of the extract and the contents were incubated at $90^{\circ} \mathrm{C}$ for $90 \mathrm{~min}$, cooled to ambient temperature and the absorbance was measured at $695 \mathrm{~nm}$. The antioxidant capacity was expressed as trolox (g/100 g of extract) equivalent.

\section{DPPH scavenging assay}

DPPH assay was used for determination of free radical scavenging of extracts following the method of Chang et al., (2001). The scavenging effects on DPPH radicals were determined by measuring the decrease in absorbance at $517 \mathrm{~nm}$ due to the DPPH radical reduction, indicating the antioxidant activity of the compounds in a short time. 10 
$\mu \mathrm{l}$ of sample $(5 \mathrm{mg} / \mathrm{ml})$ was mixed with $90 \mu \mathrm{l}$ of 50 mMTris- $\mathrm{HCl}$ buffer $(\mathrm{pH} 7.4)$ and 200 $\mu \mathrm{l}$ of $0.1 \mathrm{mM}$ DPPH-ethanol solution. When DPPH reacts with an antioxidant, it donates hydrogen and gets reduced. The resulting decrease in absorbance at $517 \mathrm{~nm}$ was recorded using a UV-Vis spectrophotometer (Thermo-Scientific, UV-Vis spectrophotometer). Trolox was used as a positive control. The results were expressed as trolox equivalents $(\mathrm{g} / 100 \mathrm{~g})$.

\section{Ferric reducing activity power (FRAP) assay}

The FRAP assay was carried out according to Stratil et al., (2006) with slight modification using freshly prepared FRAP reagent. The $200 \mu \mathrm{l}$ of methanolic extract of each sample was mixed into $1.3 \mathrm{ml}$ of the FRAP reagent. The tubes were vortexed and left at $37{ }^{\circ} \mathrm{C}$ for $40 \mathrm{~min}$, and the absorbance was measured at $595 \mathrm{~nm}$. The absorbance changes in the test mixture were compared to those obtained from standard mixture of trolox equivalent $(0.1 \mu \mathrm{m} / 1-1.0 \mu \mathrm{m} / \mathrm{l})$. FRAP values were expressed as $\mu \mathrm{M}$ trolox equivalents per gm.

\section{ABTS radical scavenging assay}

The ability of the test sample to scavenge $\mathrm{ABTS}^{+}$radical cation was compared to trolox standard (Re et al., 1999). A stock solution of ABTS radicals was prepared by mixing 5.0 $\mathrm{ml}$ of $7 \mathrm{mM}$ ABTS solution with $88 \mu \mathrm{l}$ of 140 $\mathrm{mM}$ potassium persulfate, and kept in the dark at room temperature for 12-14 hrs. An aliquot of stock solution was diluted with phosphate buffer (5 mM, pH 7.4) containing $0.15 \mathrm{M} \mathrm{NaCl}$ in order to prepare the working solution of ABTS radicals to an absorbance of $0.70 \pm 0.02$ at $734 \mathrm{~nm}$. A $65 \mu \mathrm{l}$ aliquot of sample solution was mixed with $910 \mu \mathrm{l}$ of ABTS radical working solution, incubated for 10 min at room temperature in the dark, and then absorbance was measured at $734 \mathrm{~nm}$.
The percent reduction of $\mathrm{ABTS}^{+}$to $\mathrm{ABTS}$ was calculated according to the following equation (Amadou et al., 2011):

ABTS $(\%)=1-$ (absorbance of sample/absorbance of control) x 100

\section{Results and Discussion}

The yield of extract obtained from $10 \mathrm{~g}$ of dry plant material using the three different solvents was highest for methanol (Table 1).

The total phenolic contents in the examined plant extracts using the Folin-Ciocalteu's reagent is expressed in terms of gallic acid equivalent (Table 2). The total phenolic contents in the examined extracts ranged from 1.25 to 3.98 gallic acid/100g. The bark extract showed highest concentration of phenolic content at $5 \mathrm{mg} / \mathrm{ml}$ in methanol followed by acetone and then in acidified methanol. The concentrations used to prepare extracts also showed variations. Earlier workers have also reported that high solubility of phenols in polar solvents provides high concentration of these compounds in the extracts obtained using polar solvents for the extraction (Stankovic et al., 2011; Mohesh and Ammar, 2008; Zhou and Yu, 2004). Thus it can be stated that the total phenolic contents in plant extracts of the species B. rugulosa depends on the type of extract, i.e. the polarity of solvent used in extraction.

The concentration of flavonoids in bark extracts of B. rugulosa was determined using spectrophotometric method with aluminum chloride and was expressed in terms of catechin equivalent. The total flavonoid content in extracts of different polarities from B. rugulosa showed different results in the range of 14.97 to $38.79 \mathrm{gm}$ catechin equivalents/100g. Methanolic extract of $B$. rugulosa had the highest total flavonoid content (38.79 g CE/100 g) and lowest (14.97 
$\mathrm{g} \mathrm{CE} / 100 \mathrm{~g}$ ) for the bark extract. Of the three extracts used, methanolic extract contained the highest flavonoid activity $(38.79 \mathrm{~g} / 100 \mathrm{~g})$ at $5 \mathrm{mg} / \mathrm{ml}$ concentration. However, the concentration of flavonoids in methanol extract was closer to the concentration of acetone extract concentration. The lowest flavonoid activity was measured in acidified methanol extract $(14.97 \mathrm{~g} / 100 \mathrm{~g})$ at $10 \mathrm{mg} / \mathrm{ml}$. Acetone extract also contained the highest activity at $5 \mathrm{mg} / \mathrm{ml}$, whereas acidified methanolic extract showed maximum activity at $0.5 \mathrm{mg} / \mathrm{ml}$. These results showed that the concentration of flavonoids in plant extracts depends on the polarity of solvents used in the extract preparation (Min and Chun-Zhao, 2005)

In order to determine the relationship between the level of total phenols and free radical scavenging activity, the total antioxidant activity from these extracts was estimated. Among the different extracts used with different concentrations, the highest total antioxidant activity of the methanolic extract was observed in $5 \mathrm{mg} / \mathrm{ml}$ (35.16 gm trolox equivalent) (Table 4). These results are in agreement with Banerjee et al., (2012) where they reported that the polar solvent had the higher antioxidant activities. However, different concentrations of the extracts showed remarkable variation in the activity. Acetone extract with $0.5 \mathrm{mg} / \mathrm{ml}$ concentration showed maximum activity (24.48 gm trolox equivalent) whereas acidified methanolic extract showed minimum activity (15.36 $\mathrm{mg} / \mathrm{ml}$ ) at $10 \mathrm{mg} / \mathrm{ml}$ concentration. All the three extract showed higher activity at 5 $\mathrm{mg} / \mathrm{ml}$ with slight variation in acetone and acidified methanol extracts.

The antioxidant activity of bark extracts using the three solvent systems with three different concentrations was determined by DPPH reagent. A freshly prepared DPPH solution exhibits a deep purple colour with absorption maxima at $517 \mathrm{~nm}$. The intensity of purple colour generally decreases when antioxidant molecules quench DPPH free radicals by providing hydrogen atoms and thereby converting them into a bleached product 2,2diphenyl-1-hydrazine. This conversion into a substituted analogous hydrazine results in a decrease in absorbance at $517 \mathrm{~nm}$ (Amarowicz et al., 2003). The obtained values for DPPH radical scavenging varied from 1.40 to 3.27 trolox equivalent for different extracts with the methanolic extract being the most effective among the three extracts. The DPPH racial scavenging activity of the extract was higher at $5.00 \mathrm{mg} / \mathrm{ml}$ concentration i.e. $3.00 \mathrm{mg} / \mathrm{g}$ DPPH racial scavenging. These results are in agreement with Stankovic (2011) where he observed that methanolic extract from $M$. peregrinum manifested the strongest capacity for neutralization of DPPH radicals.

The antioxidant capacities using FRAP, ABTS and DPPH assays of different polar extracts from bark extracts are shown in Table 5.

In FRAP method, antioxidant capacities are in the range of $7.3-33.8 \mu \mathrm{M}$ trolox equivalents for different extracts. Methanolic extract exhibited highest FRAP capacity $(33.8 \mu \mathrm{M}$ trolox equivalents), while the lowest capacity (7.3 $\mu \mathrm{M}$ trolox equivalents) was shown by acidified extract. FRAP assay measures the ability of the plant extracts to reduce ferric to ferrous at low $\mathrm{pH}$ causing the formation of ferrous-tripyridyltriazine complex (Fidrianny et al., 2014). The methanol extract at $5 \mathrm{mg} / \mathrm{ml}$ exhibited better ferric reducing property than acetone and acidified methanol extracts.

For ABTS scavenging activity also methanolic extract showed highest scavenging capacity (99.59\% inhibition) towards quenching of ABTS, whereas acidified methanolic acid had lowest \% 
inhibition (62.01\%). A moderate activity was found for acetone extracts. The extraction of antioxidant substances of different chemical structure was achieved using solvents of different polarity. The results are based on the ability of an antioxidant to decolorize the $\mathrm{ABTS}^{+}$cation radical.

Table.1 The yields of solid residue after extraction and evaporation from $10 \mathrm{~g}$ dried plant parts

\begin{tabular}{|l|c|c|c|}
\hline Extract yields $(\mathbf{g})$ & \multicolumn{3}{|c|}{ Concentration $(\mathbf{m g} / \mathbf{m l})$} \\
\hline Solvents & $\mathbf{0 . 5}$ & $\mathbf{5}$ & $\mathbf{1 0}$ \\
\hline Methanol & $0.84 \pm 0.06$ & $0.88 \pm 0.07$ & $0.86 \pm 0.02$ \\
\hline Acetone & $0.71 \pm 0.01$ & $0.72 \pm 0.02$ & $0.70 \pm 0.02$ \\
\hline Acidified methanol & $0.46 \pm 0.03$ & $0.49 \pm 0.02$ & $0.46 \pm 0.01$ \\
\hline
\end{tabular}

Each value is the average of three measurements \pm standard deviation

Table.2 Total phenolic contents in the plant extracts expressed in terms of gallic acid equivalent (gm of GA/100g of extract)

\begin{tabular}{|l|c|c|c|}
\hline & \multicolumn{3}{|c|}{ Concentration (mg/ml) } \\
\hline Solvents & $\mathbf{0 . 5}$ & $\mathbf{5}$ & $\mathbf{1 0}$ \\
\hline Methanol & $1.68 \pm 0.09$ & $3.98 \pm 0.22$ & $1.39 \pm 0.05$ \\
\hline Acetone & $1.94 \pm 0.07$ & $1.80 \pm 0.09$ & $1.25 \pm 0.10$ \\
\hline Acidified methanol & $1.86 \pm 0.11$ & $2.52 \pm 0.10$ & $3.17 \pm 0.17$ \\
\hline
\end{tabular}

Each value is the average of three analyses \pm standard deviation.

Table.3 Concentrations of flavonoids in the plant extracts expressed in terms of equivalent (gm of $\mathrm{CE} / \mathrm{g}$ of extract)

\begin{tabular}{|l|c|c|c|}
\hline & \multicolumn{3}{|c|}{ Concentration (mg/ml) } \\
\hline Solvents & $\mathbf{0 . 5}$ & $\mathbf{5}$ & $\mathbf{1 0}$ \\
\hline Methanol & $32.53 \pm 1.85$ & $38.79 \pm 1.26$ & $21.22 \pm 2.13$ \\
\hline Acetone & $22.11 \pm 1.69$ & $25.44 \pm 0.98$ & $16.27 \pm 0.66$ \\
\hline Acidified methanol & $21.82 \pm 2.15$ & $15.42 \pm 0.89$ & $14.97 \pm 0.84$ \\
\hline
\end{tabular}

Each value is the average of three analyses \pm standard deviation.

Table.4 Concentrations of total antioxidant activity in the plant extracts expressed in terms of trolox equivalent (gm of trolox/g of extract)

\begin{tabular}{|l|c|c|c|}
\hline & \multicolumn{3}{|c|}{ Concentration (mg/ml) } \\
\hline Solvents & $\mathbf{0 . 5}$ & $\mathbf{5}$ & $\mathbf{1 0}$ \\
\hline Methanol & $31.13 \pm 0.61$ & $35.16 \pm 0.95$ & $21.99 \pm 0.82$ \\
\hline Acetone & $24.48 \pm 0.55$ & $23.14 \pm 2.97$ & $17.23 \pm 1.96$ \\
\hline Acidified methanol & $21.28 \pm 1.58$ & $19.18 \pm 1.05$ & $15.36 \pm 1.23$ \\
\hline
\end{tabular}


Table.5 Concentrations of different antioxidant activity (DPPH, FRAP, ABTS) in the bark extracts

\begin{tabular}{|c|c|c|c|c|c|c|c|c|c|}
\hline \multirow[b]{2}{*}{ Solvents } & \multicolumn{3}{|c|}{ DPPH } & \multicolumn{3}{|c|}{ FRAP } & \multicolumn{3}{|c|}{ ABTS } \\
\hline & $\begin{array}{c}0.5 \\
(\mathrm{mg} / \mathrm{ml})\end{array}$ & $\begin{array}{c}5 \\
(\mathrm{mg} / \mathrm{ml}\end{array}$ & $\begin{array}{c}10 \\
(\mathrm{mg} / \mathrm{ml} \\
)\end{array}$ & $\begin{array}{c}0.5 \\
(\mathrm{mg} / \mathrm{ml})\end{array}$ & $\begin{array}{c}5 \\
(\mathrm{mg} / \mathrm{ml})\end{array}$ & $\begin{array}{c}10 \\
(\mathrm{mg} / \mathrm{m} \\
\mathrm{l})\end{array}$ & $\begin{array}{c}0.5 \\
(\mathrm{mg} / \mathrm{ml})\end{array}$ & $\begin{array}{c}5 \\
(\mathrm{mg} / \mathrm{ml})\end{array}$ & $\begin{array}{c}10 \\
(\mathrm{mg} / \mathrm{ml})\end{array}$ \\
\hline Methanol & $\begin{array}{c}2.71 \pm 0.0 \\
00\end{array}$ & $\begin{array}{c}2.7 \pm 0.0 \\
00\end{array}$ & $\begin{array}{c}1.4 \pm 0.0 \\
00\end{array}$ & $\begin{array}{c}17.16 \pm .2 \\
05\end{array}$ & $\begin{array}{c}33.8 \pm .00 \\
7\end{array}$ & $\begin{array}{c}13.7 \pm . \\
006\end{array}$ & $\begin{array}{c}69.742 \pm 1 . \\
605\end{array}$ & $\begin{array}{c}88.145 \pm 1 . \\
383\end{array}$ & $\begin{array}{c}99.599 \pm . \\
308\end{array}$ \\
\hline Acetone & $\begin{array}{c}3.27 \pm .00 \\
4\end{array}$ & $\begin{array}{c}3.0 \pm .00 \\
1\end{array}$ & $\begin{array}{c}1.5 \pm .00 \\
0\end{array}$ & $\begin{array}{c}20.51 \pm .2 \\
21\end{array}$ & $\begin{array}{c}26.8 \pm .01 \\
7\end{array}$ & $\begin{array}{c}7.3 \pm .0 \\
04\end{array}$ & $\begin{array}{c}65.575 \pm 7 . \\
524\end{array}$ & $\begin{array}{c}76.339 \pm 0 . \\
394\end{array}$ & $\begin{array}{c}97.554 \pm . \\
000\end{array}$ \\
\hline $\begin{array}{l}\text { Acidified } \\
\text { methanol }\end{array}$ & $\begin{array}{c}2.93 \pm .01 \\
0\end{array}$ & $\begin{array}{c}2.5 \pm .00 \\
0\end{array}$ & $\begin{array}{c}1.4 \pm .00 \\
0\end{array}$ & $\begin{array}{c}30.7 \pm .05 \\
0\end{array}$ & $\begin{array}{c}24.8 \pm .00 \\
7\end{array}$ & $\begin{array}{c}14.2 \pm . \\
006\end{array}$ & $\begin{array}{c}62.007 \pm 5 \\
872\end{array}$ & $\begin{array}{l}80.964 \pm 0 . \\
345\end{array}$ & $\begin{array}{c}98.283+0 \\
.00\end{array}$ \\
\hline
\end{tabular}

Figure.1a Colinear relationships between nutritional parameters studied at $0.5 \mathrm{mg} / \mathrm{ml}$ concentration

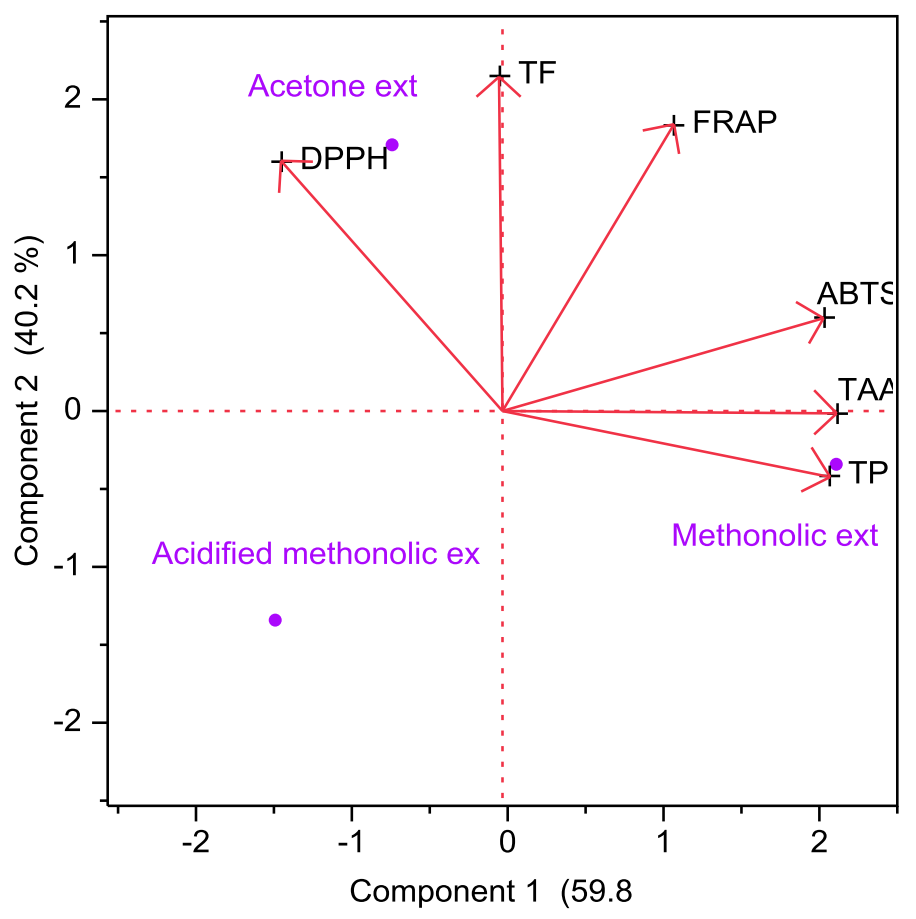


Figure.1b Colinear relationships between nutritional parameters studied at $5 \mathrm{mg} / \mathrm{ml}$ concentration

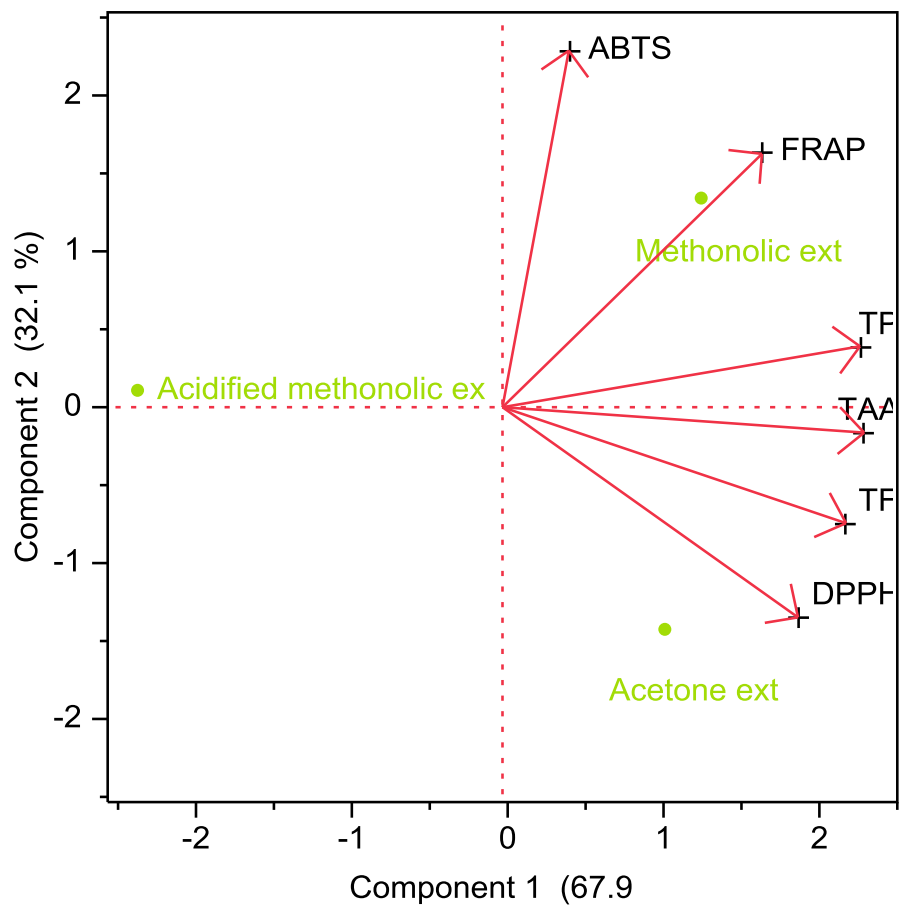

Figure.1c Colinear relationships between nutritional parameters studied at $10 \mathrm{mg} / \mathrm{l}$ concentration

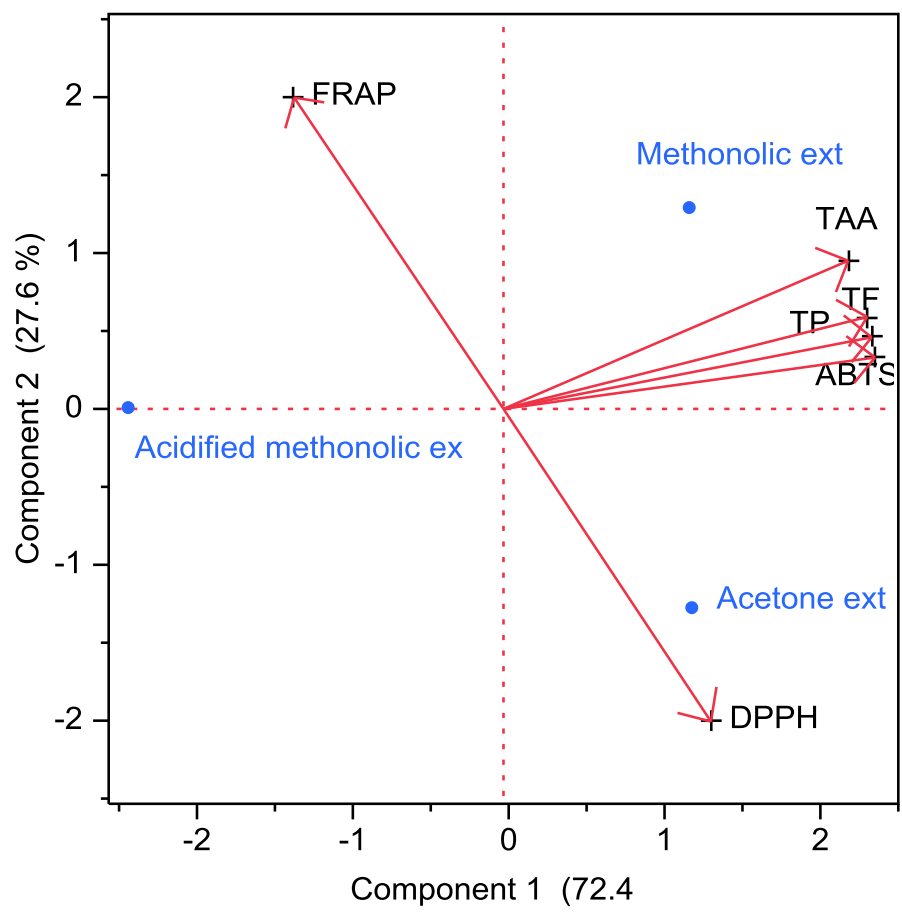


Phenolic compounds have antioxidant properties and can protect against degenerative diseases, such as heart diseases and cancer, in which reactive oxygen species like superoxide anion, hydroxyl radicals and peroxy radicals are involved (Rhodes and Price, 1997; Tosun et al., 2009). A significant linear correlation was found between the values for the concentration of phenolic compounds and the antioxidant activity of extracts from B. rugulosa (Figure 1a,b,c). Similar results with high linear correlation between the values of phenol concentration and antioxidant activity were observed by Canadanovic-Brunet et al., (2008), Borneo et al., (2008), Katalinic et al., (2004) and Yeasmen and Islam (2015) .

Plant phenolics have been recognized to be a therapeutic target for cancer treatment and cardiovascular disease in the next decades (Fidriyani et al., 2014) and also have the ability to prevent oxidant potentials of free radicals as natural source of antioxidants. Stankovic (2011) reported the presence of high concentrations of phenols in the extracts obtained using polar solvents. They also reported that extracts with highest antioxidant activity have the highest concentration of phenolic acids also. Numerous other studies also mention that phenolic content of plants may contribute directly to their antioxidant action (Koczka et al., 2015; Tosun et al., 2009; Stankovic, 2011). Thus, phenolic compounds are potentially health promoting due to their antioxidant property.

Flavonoids are a group of polyphenolic compound with known free radical scavenging activity (Frankel et al., 1995). A positive correlation between total phenolic content and free radical scavenging activity has been reported earlier also (Koczka et al., 2015). Thus, it can be inferred that the polyphenolics present in Gethi (Boehmeria rugulosa) contribute to the antioxidant property. Methanolic extract of gethi bark showed high value of total phenolics and flavonoids indicating high antioxidant activity in the subsequent assays.

The methanol extracts of leaves of Acorus calamus have also shown striking DPPH scavenging activity (at $20 \mu \mathrm{g} / \mathrm{mL}$ ), ferric ion chelating potential (at $18.8 \mu \mathrm{g} / \mathrm{ml}$ ) and reductive ability (concentration dependant) whereas, methanol extract of rhizome exhibited better superoxide radical scavenging potential (at $30.5 \mu \mathrm{g} / \mathrm{mL}$ ) (Devi and Ganjewala, 2011). Further, it has been reported earlier also that total phenolic content and total flavonoid content of Gethi bark powder is substantially higher than finger millet and sorghum (Khulbe et al., 2014).

In this study we report that all the three extracts under study exhibited concentration dependent free radical scavenging activity, and also that at $5 \mathrm{mg} / \mathrm{ml}$ concentration of methanol extract of Gethi bark powder exhibited higher phenolic acid content flavonoid content, total antioxidant activity with slight variations. The higher antioxidant activity and higher content of healthpromoting phenolics and flavonoids in Gethi bark powder make it additionally beneficial as a food ingredient.

In conclusion the results of the present study reveal the potential value of Gethi (Boehmeria rugulosa) bark in pharmacy and therapeutics. Methanolic extract exhibited greater potency for extraction of phenolic compounds from Gethi (Boehmeria rugulosa) than other solvents showing that solvents of high polarity yield highest concentration of phenolic compounds, flavonoid content and total antioxidant activity in the extracts. The high content of phenolic compounds and significant linear correlation between the concentration of phenolic compounds, 
flavonoid content and antioxidant activity indicated that these compounds contribute to the high antioxidant activity of the bark. Based on this information it may be concluded that Boehmeria rugulosa is a good source of antioxidant substances of high importance. Further studies on this plant species need to be directed on the formulation of natural pharmaceutical products of high value using its natural active components.

\section{Acknowledgements}

The authors gratefully acknowledge the farmers of Gram Panchatat Mudiyani (Dist. Champawat, Uttarakhand) for providing valuable information on the traditional use of bark of Boehmeria rugulosa. The necessary facilities extended by ICAR-VPKAS, Almora for carrying out the study is also thankfully acknowledged.

\section{References}

Adamu, M., Naidoo, V., and Eloff, J. N. 2014. The antibacterial activity, antioxidant activity and selectivity index of leaf extracts of thirteen South African tree species used in ethnoveterinary medicine to treat helminth infections. BMC Veterinary Research. 10:52. DOI: 10.1186/17466148-10-52.

Amadou, I., Gbadamosi, O. S. and Guo-Wei, L. 2011. Millet- based traditional processed foods and beverages - A review. Cereal Food World. 56 (3):115-121.

Amarowicz, R., Pegg, B. R., Rahimimoghaddam, P., Bar, B., Weil, J. A. 2003. Free-radical scavenging capacity and antioxidant activity of selected plant species from the Canadian prairies. Food Chemistry. 84:551-562.
Anubhuti Sharma, Salej Sood, P.K. Agrawal, L., Kant, J.C. Bhatt and A. Pattanayak. 2016. Detection and Assesment of Neutraceuticals in Methanolic Extracts of Finger (Elusine coracana) and Barynyard Millet (Echonochloa frumentacea). Asian Journal of Chemistry. 28 (7): 1633-1637.

Banerjee, S., Sanjay, K. R., Chethan, S. and Malleshi, N. G. 2012. Finger millet (Eleusine coracana) polyphenols: Investigation of their antioxidant capacity and antimicrobial activity. African Journal of Food Science. 6(13) :362-374.

Borneo, R., Leon, E. A., Aguirre, A., Ribotta, P., Cantero, J. J. 2008. Antioxidant capacity of medicinal plants from the Province of Cordoba (Argentina) and their in vitro testing in model food system. Food Chemistry. 112: 664670.

Canadanović-Brunet, J., Cetković, G., Djilas, S., Tumbas, V., Bogdanović, G., Mandić, A., Markov, S., Cvetković, D., Canadanović, V. 2008. Radical scavenging, antibacterial, and antiproliferative activites of Melissa officinalis L. extracts. J. Med. Food. 11: 133-143.

Chang, S.T., Wu, J.H., Wang, S.Y., Kang, P. L., Yang, N.S. and Shyur, L.F. 2001. Antioxidant Activity of Extracts from Acacia confusa Bark and Heartwood. J. Agric. Food Chem. 49 :3420-3424.

Demiray, S., Pintado, M.E. and Castro, L.M.P. 2009. Evaluation of Phenolic profiles and antioxidant activities of Turkish medicinal plants Tilia argentea, Crataegi folium leaves and Polygonum bistorta roots. World Acad Sci Eng Technol. 54:312-317.

Devasagayam, T. P. A., Tilak, J. C., Boloor, K. K., Ketaki, Sane S., Saroj, S. Ghaskadbi, Lele R. D. 2004. Free Radicals and Antioxidants in Human 
Health: Current Status and Future Prospect. Journal of Physicians of India. 52:794-804.

Devi, S.A. and Ganjewala, D. 2011. Antioxidant Activities of Methanolic Extracts of Sweet-Flag (Acorus calamus) Leaves and Rhizomes. Journal of Herbs, Spices \& Medicinal Plants. 17(1):1-11.

Fidrianny, I., Darmawati, A., Sukrasno. 2014. Antioxidant capacities from different polarities extracts of Cucurbitaceae leaves using FRAP, DPPH assays and correlation with Phenolic, Flavonoid, Carotenoid content. International Journal of Pharmacy and Pharmaceutical Sciences. 6: 858-862.

Frankel, E.N., Waterhouse, A.L. and Teissedre, P.L. 1995. Principal phenolic phytochemicals in selected California wines and their antioxidant activity inhibiting oxidation of human low-density lipoprotein. J. Agric. Food Chem. 43: 890-4.

Katalinic, V., Milos, M., Kulisic, T., Jukic, M. 2004. Screening of 70 medicinal plant extracts for antioxidant capacity and total phenols. Food Chemistry. 94:550-557.

Khulbe, R.K., Sood, S., Sharma, A., Agrawal, P.K. and Bhatt, J.C. 2014. Value addition anh nutritional fortification of finger millet (Eleusine coracana $L$. Gaertn.) using bark of Gethi (Boehmeria regulosa wedd.) tree. Indian Journal of Traditional Knowledge. 13 (3):519-524.

Koczka, N., Moczar, Z., Stefanovits- Banyai, E., Ombodi, A. 2015. Differences in antioxidant properties of ginkgo leaves collected from male and female trees. Acta Pharmaceutica. 65:99-104. DOI: 10.1515/acph-2015-0001

Margaret, E., Shailaja, A. M. and Venugopal, Rao. V. 2015. Evaluation of Antioxidant Activity in Different Parts of Syzygium cumini (Linn.). Int. J. Curr. Microbiol. App. Sci. 4(9):372379.

Min, G. and Chun-Zhao, L. 2005. Comparison of techniques for the extraction of flavonoids from cultured cells of Saussurea medusa Maxim. World J. Microb. Biot. 21: 1461-1463.

Mohsen, M.S. and Ammar, S.M.A.2008. Total phenolic contents and antioxidant activity of corn tassel extracts. Food Chem. 112:595-598.

Mulabagal, V. and Tsay, Hsin-Sheng. 2004. Plant Cell Cultures - an alternative and efficient source for the production of biologically important secondary metabolites. International Journal of Applied Science and Engineering. 2:29-48.

Naskar, S., Mazumdar, U.K., Pramanik, G., Bala, A., Haldar, P.K., Islam, A., Gupta, M. 2011. Comparative in vitro anti oxidant activity of different parts of Cocos nucifera Linn. on reactive oxyzen and nitrogen species. International Journal of Pharmacy and Pharmaceutical Sciences. 3: 104-107.

Prieto, P., Pineda, M. and Aguilar, M. 1999. Spectrophotometric quantitation of antioxidant capacity through the formation of a phosphomolybdenum complex: specific application to the determination of vitamin E. Anal. Biochem. 269:337-341.

Re, R., Pellegrini, N., Proteggente, A., Pannala, A., Yang, M. and RiceEvans, C. 1999. Antioxidant activity applying an improved ABTS Radical cation decolorization assay. Free radical Biology and Medicine. 26: 1231-1237.

Rehman, Z.U. 2006. Citrus peel extract-a natural source of antioxidant.Food Chem. 99 :450-454.

Rhodes, M. J. and Price, K. R. 1997. Identification and analysis of plant 
phenolic antioxidants. European Journal of Cancer Prevention. 6 (6): $518-521$.

Sharma, A., Gupta, P. and Verma, A. K. 2013. Preliminary nutritional and biological potential of Artocarpus heterophyllus $L$. shell powder. Journal of Food Science \& Technology. DOI 10.1007/s13197-013-1130-8.

Sharma, Anubhuti, Kumar, Arun, Meena, Hari Singh and Singh, Dhiraj. 2016. Chromatographic Determination of Phenolics in the Brassica juncea. Asian Journal of Chemistry. 28 (2); 296-300.

Singleton, V.L., Orthofer, R., LamuelaRaventos, R.M. 1999. Analysis of total phenols and other oxidation substrates and antioxidants by means of Folin-Ciocalteu reagent. Methods Enzymol. 299: 152-179.

Stankovic, M.S. 2011. Total phenolic content, flavonoid concentration and antioxidant activity of Marrubium peregrinum L. extracts. Kragujevac J. Sci. 33: 63-72.

Stratil, P., Klejdus, B. and Kuban, V. 2006. Determination of total content of phenolic compounds and their antioxidant activity in vegetables-evaluation of spectrophotometric methods. Agric. Food Chem. 54(3): 607-616.

Tosun, M., Ercisli, S., Sengul, M., Ozer, H., Polat, T, and Ozturk, E. 2009. Antioxidant Properties and Total Phenolic Content of Eight Salvia Species from Turkey. Biol Res. 42: 175-181.

Venkateswara, Rao S., Ayya, Raju M. and Kammakshamma, J. 2013. Phytochemical screening and antioxidant activity of bark extracts of Chionanthus zeylanica Linn. as an important medicinal plant in Eastern Ghats. International Journal of Drug Development and Research. 5(2): 311316.

Yeasmen, N. and Islam, Md N. 2015. Ethanol as a solvent and hot extraction technique preserved the antioxidant properties of tamarind (Tamarindus indica) seed. Journal of Advanced Veterinary and Animal Research. 2(3): 332-337.

doi: 10.5455/javar.2015.b103

Zhou, K. and Yu, L. 2004. Effects of extraction solvent on wheat bran antioxidant activity estimation. LWTFood Science and Technology. 37: 717-721.

\section{How to cite this article:}

Anubhuti Sharma, Rajesh Khulbe, Salej Sood, Pawan Kumar Agrawal, Jagdish Chandra Bhatt and Arunav Pattanayak. 2017. A Simple Method for the Characterization of Antioxidant Property of Different Extracts of Bark of Gethi (Boehmeria rugulosa). Int.J.Curr.Microbiol.App.Sci. 6(4): 2635-2645. doi: https://doi.org/10.20546/ijcmas.2017.604.306 